Volume: 1 | Number 1 | pp. $23-43$

ISSN: 2633-352X (Print) | ISSN: 2633-3538 (Online) journals.tplondon.com/ijor

First Submitted: 2 July 2020 Accepted: 1 November 2020

DOI: https://doi.org/10.33182/ijor.v1i1.1073

\title{
Creating the Internal Enemy: Opportunities and Threats in Pro and Anti-LGBT Activism within South Korean Protestantism
}

\author{
Hendrik Johannemann ${ }^{1}$
}

\begin{abstract}
In recent years, South Korea has experienced significant mobilization against LGBT rights, mainly emanating from conservative Protestant forces. This anti-LGBT mobilization bas been attributed to the need to create an "external enemy" as a means for covering up internal scandals. This study examines how the Protestant anti-LGBT movement creates an "internal enemy", too, by fighting against pro-LGBT activism and attitudes within its faith. Applying the contentious politics and movementcountermovement frameworks to the study of religious conflict, the article uncovers the mechanisms at work in the complex interactions among anti-LGBT, moderate, and LGBT-affirmative actors. The analysis of five cases - beresy trials against a proLGBT pastor, conflicts at Christian universities, vilifications of a progressive Christian online newspaper and a church association, and the controversy around a moderate junior pastor - shows that perceived and deliberately created threats play a productive, opportunity-like role in religious contention over LGBT issues. Longstanding religiopolitical cleavages come to the fore, too, involving conflictual relations with state actors external to Korean Protestantism.
\end{abstract}

Keywords: pro and anti-LGBT activism; South Korean Protestantism; opportunities and threats; contentious politics; movement-countermovement dynamics

\section{Introduction: Contention over LGBT issues in Korean Protestantism and beyond}

In South Korea (henceforth: Korea), conservative Protestant groups have been fighting against various political initiatives in favor of lesbian, gay, bisexual, and transgender (LGBT) rights since the early 2000s. Anti-LGBT campaigns, many of which were successful, included campaigns against antidiscrimination bills, against human rights ordinances, against gay men in the Korean military, and against school textbooks disseminating information on homosexuality. Recent scholarship considers several explanatory avenues for the emergence of anti-LGBT activism in South Korea, arguing, for example, that while the Christian doctrine may play an important role in the fight against homosexuality, the decisive reason is to be found in the crisis of Korean Protestantism. By focusing on the opposition against LGBT issues, church leaders and professionalized anti-LGBT groups try to deflect attention away from declining church memberships and scandals like embezzlement and sexual harassment (Shiwoo, 2018: 36-46). In Han's view, conservative Protestant church leaders use anti-gay rhetoric to create an "external enemy" or threat to help increase their political leverage and at the same time lessen the divisions among notoriously fragmented denominations (Han, 2017: 180181).

Existing social scientific research on conservative Christian opponents of LGBT rights mainly investigates how Christian forces strive to prevent or undo pro-LGBT legislation in the arenas of

${ }^{1}$ Hendrik Johannemann, Freie Universität Berlin, Germany. E-mail: hendrik.johannemann@fu-berlin.de 


\section{Opportunities and Threats in Pro and Anti-LGBT Activism within South Korean Protestantism}

politics and law (Kim, 2016 on Korea; Hark \& Villa, 2015 on Germany; Béraud \& Portier, 2015 on France; Stone, 2016; Dorf \& Tarrow, 2014; Fejes, 2008; Fetner, 2008; Green, 2000; Herman, 1997 on the United States). Taking the example of Korea, this study examines how anti-LGBT activists create an "internal enemy" by fighting and vilifying LGBT-affirmative tendencies within Protestantism - going beyond theological and attitudinal (Moon, 2014; Rich, 2016; Choi, 2014) as well as exclusively political disputes. This perspective on the dynamics between Christian pro and anti-LGBT groups complements similar studies, for example on LGBT groups at Christian universities in the United States (Coley, 2018, 2017, 2014) by taking into consideration a broader range of forms and arenas of contention. ${ }^{2}$ Korea is a worthwhile case study for at least three reasons: it features a rather strong anti-LGBT movement based in conservative Protestantism. ${ }^{3}$ Korean Protestantism in general is characterized by a high degree of factionalization and internal conflicts (Clark, 2008: 220). Finally, Korea can serve as an example of how religious contention over LGBT issues works in a non-western context.

Protestant anti-LGBT activists and LGBT-affirmative actors enter into various forms of struggles, which are analyzed by adapting the contentious politics framework (Tilly \& Tarrow, 2015; Tarrow, 2011; McAdam et al., 2001) and movement-countermovement dynamics (Meyer \& Staggenborg, 1996) for the study of religious conflict. These approaches emphasize the importance of interaction between collective actors and their opponents. They focus on the interplay of "members" and "challengers", i.e., between actors with power or access to powerful parts of a certain community and actors who challenge the former's position or worldview. This conceptual lens helps understand what a crucial role perceived or deliberately constructed threats and opportunities play in this interaction. By concentrating on relational, cognitive, and constructivist aspects, this investigation identifies the mechanisms at work as well as the action repertoires used in the contentious relations among anti-LGBT, moderate, and LGBT-affirmative actors within Korean Protestantism.

I argue that the attacks against pro-LGBT stances within Protestantism are crucial to understand the motivations, strategy, and the complex actor constellations of Protestant anti-LGBT activism in Korea. Many major Protestant denominations and their anti-LGBT factions aim at creating an image of Korean Protestantism standing united against homosexuality and related, allegedly anti-Christian "ills". This unity, however, shows distinct cracks. Dissent does not only arise between an uncompromising anti-LGBT camp and other conservative, yet more moderate voices. Explicitly affirmative attitudes have also become visible in recent years.

This study has two main findings. First, through being framed as a threat, LGBT-affirmative activism within Protestantism can be strategically utilized as an additional incentive to fight LGBT issues. The anti-LGBT movement can stress the urgency to eliminate this threat, thus trying to mobilize fellow believers for the struggle against an "internal enemy". Second, despite these efforts of anti-LGBT factions, practicing Christian LGBT individuals and their allies have become more active and gained greater visibility owing to the very oppression originating from their bellicose Christian "fellows".

\footnotetext{
2 This study goes beyond perspectives that focus on one party or aspect of the conflict only, like the Korean LGBT movement (Kwon Kim \& Cho, 2011; Bong, 2009; Park-Kim et al., 2006), benevolent Christian congregations in Seoul (Yi et al., 2017), ex-gay activism within the Christian anti-LGBT movement (Pak, 2018), the latter's transnational connections (Yi et al., 2017), anti-LGBT "scientific" argumentative strategies (Baek, 2018), and the human rights discourse on the proposed anti-discrimination bills in Korea (Kim, 2019).

${ }^{3}$ Protestant Christianity makes up about $21 \%$ of the Korean population, Catholicism 7\%, Buddhism 24\% (Baker, 2016: 46). For general perspectives on the history and the development of Korean Protestantism, especially its phenomenal growth during Korean industrialization from the 1960s onwards, see Baker (2016), Buswell and Lee (2006). For more detailed studies on Korean Protestantism's theological conservatism and fundamentalism, see Hwang (2008) and Kang (2004).
} 
The study builds on a qualitative content analysis ${ }^{4}$ of articles from the conservative Christian daily newspaper Kukmin Daily (kungmin ilbo). ${ }^{5}$ I consciously chose this newspaper for its frequent and negatively biased reporting on LGBT issues, presuming it covers more instances of LGBT-related contention than other major newspapers. ${ }^{6}$ For a larger research project, ${ }^{7}$ I singled out all the Kukmin Daily articles including the search term "tongsŏngae" ("homosexuality") for the period of January 1990 till April 2020 and subsequently selected the pieces covering instances of anti-LGBT activism in Korea. I then used this database to identify cases of protracted strife over LGBT issues inside Korean Protestantism, which constitute the specific sub-cases to be analyzed here. Other newspaper articles and press statements from relevant organizations will also be included to complement the datasets of the identified cases and to remedy Kukmin Daily's anti-LGBT bias. I found that concrete internal struggles over LGBT issues only emerged and soon substantially expanded from 2015 onwards.

The article will proceed as follows: after presenting the analytical framework, I offer an overview of the contentious interactions over LGBT issues within Korean Protestantism and beyond. The main body of the study consists of an analysis of five case studies, namely heresy trials against a pro-LGBT pastor, conflicts at Christian universities, the vilification of the progressive National Council of Churches in Korea and the Christian newspaper Newsnjoy, and the controversy around an arguably moderate junior pastor of a Protestant congregation. The conclusion summarizes and further contextualizes the results of my analysis.

\section{Contentious politics and movement-countermovement dynamics in the religious context}

Religious movements have been analyzed from various angles, including cultural or ideological and organizational approaches (Kniss \& Burns, 2004: 696). Further areas of research encompass the intersection of genuinely political movements with religious ones, their respective collective identities, and strategies pursued in relation to the state or society at large (Snow \& Beyerlein, 2019: 576-580). This study deals with two specific subsets of research on religious movements and adds a third aspect: social movements within religious organizations, religion as a resource or facilitator for the emergence of movements and their actions (Kniss \& Burns, 2004: 695), and religious conflict. While conflict between religious groups is not unusual and has been the subject of extensive scientific investigation, a systematic analysis of such an actor constellation - especially concerning contention

\footnotetext{
${ }^{4}$ Qualitative content analysis as applied in this study is a systematic, rule-based and thus replicable technique to analyze different types of communication (Mayring, 2015: 468). I followed Kuckartz' (2014) approach, building categories both deductively (based on the contentious politics and movement-countermovement framework) and inductively (to guarantee openness for new findings and theorization) and have coded the dataset accordingly, using the MAXQDA software. This approach is an explicitly qualitative one, since it does not quantify textual units, but rather aims at focusing on the concrete content of the original text while at the same time taking into consideration its communicational context (Mayring, 2015: 469).

5 Korean terms and organization names are transliterated using the McCune-Reischauer romanization system. Should different transliterations be common, these will be used, followed by the italicized McCune-Reischauer version in brackets the first time the term appears in the text. Korean names are presented in the Korean order (surname - name), unless indicated differently by the persons cited themselves. All direct and indirect quotes from original Korean texts are my own translations.

\begin{abstract}
${ }^{6}$ Kukmin Daily was established in 1988 by Cho Yonggi, founder of the Yoido Full Gospel Church, one of the largest Christian congregations worldwide. Kukmin Daily praises itself as "the only national Christian general-interest daily newspaper in the world” (Kang 2013). In comparison to other conservative daily newspapers with a wider circulation than Kukmin Daily (Chosun Daily, Dong-a Daily, and JoongAng Daily), Kukmin Daily covers Christian issues preferentially, also including a specifically Christian section called "Mission Life". Kukmin Daily was selected for analysis also because it is more widely known and has, presumably, a larger readership than other conservative Christian media like the online-only Christian Today (k'ǔrisǔch'ŏn t'udei).
\end{abstract}

7 i.e., the author's PhD thesis on the contentious politics of the Korean anti-LGBT movement in general, which is work in progress. 
over LGBT issues in religious contexts - is still lacking. This study will fill this lacuna by applying and adapting two approaches commonly used for the study of conflict in social movement studies: movement-countermovement dynamics and the contentious politics framework.

Protestant anti-LGBT and pro-LGBT actors in Korea enter into diverse conflicts with each other, one reacting to the other's actions and vice-versa. Social movement scholars speak of "movementcountermovement dynamics" (Meyer \& Staggenborg, 1996) or “opposing movements" (Dugan, 2004) when referring to such actor constellations. While this article is not so much concerned with the circumstances around the emergence of countermovements, it will still show that the opportunity structures identified in Meyer and Staggenborg's seminal article (1996: 1635-1643) play an important role in the dynamic interactions between religious pro and anti-LGBT actors. These opportunity structures include the following aspects: the opposing movement shows signs of success, it poses a threat to vested interests or values of dissenting groups, and it receives support from elite allies.

Concerning the role of threats and elite actors, the contentious politics approach (Tilly \& Tarrow, 2015; Tarrow, 2011; McAdam et al., 2001) is a helpful complement to the analytical framework of this study. The approach transcends the traditional social movements approach by taking into consideration a less restricted set of actors, ${ }^{8}$ and it highlights the environmental, relational, and cognitive mechanisms at work in contentious interactions. ${ }^{9}$ McAdam et al. (2001: 5) define contentious politics as "episodic, public, collective interaction among makers of claims and their objects when (a) at least one government is a claimant, an object of claims, or a party to the claims and (b) the claims would, if realized, affect the interests of at least one of the claimants." The "political" bias of this definition may pose problems to the analysis of religious contexts. McAdam and Tarrow (2011: 5) themselves acknowledge that such a state-centeredness excludes many phenomena worthy of study. I contend that by reconceptualizing the government from the definition above as a powerful, authoritative religious body, this bias can be remedied for the purpose of this study. Authoritative religious bodies are important because they wield power over subordinate religious organizations and individual believers. Moreover, they define what kind of attitudes and actions are legitimate from a perspective of religious doctrine and ethics. Influential religious actors possess capacities similar to those of (authoritarian) states. For example, they have a repressive potential, repression being defined as "efforts to suppress either contentious acts or groups and organizations responsible for them" (McAdam et al., 2001: 69, originally italicized). ${ }^{10}$ Certification and decertification represent important mechanisms for (de)mobilization in this context: "Certification entails the validation of actors, their performances, and their claims by external authorities. Decertification is the withdrawal of such validation by certifying agents" (McAdam et al.,

\footnotetext{
${ }^{8}$ Tarrow defines social movements as "collective challenges, based on common purposes and social solidarities, in sustained interaction with elites, opponents, and authorities" (Tarrow, 2011: 9, originally italicized). I argue that the general properties of this definition apply to the Korean anti-LGBT movement within Protestantism, but less so to LGBT-affirmative activism inside Korean Protestantism. As we shall see, pro-LGBT activities often take place on an ad-hoc basis and are rather uncoordinated, at least when excluding the services offered by certain churches or groups like "Rainbow Jesus" (mujigae yesu) that explicitly cater LGBT Christians. For perspectives on religious movements and their particularities see Snow and Beyerlein (2019) and Kniss and Burns (2004).

${ }_{9}^{9}$ McAdam et al. (2001: 24) define mechanisms as "a delimited class of events that alter relations among specified sets of elements in identical or closely similar ways over a variety of situations." Mechanism-based social scientific research represents an alternative to variable-based, quantitative methods and seeks to explain causality in procedural terms (Hedström \& Ylikoski, 2010; Tilly, 2001).

${ }^{10}$ Repression can take abstract forms as well. If, for example, a certain religious doctrine presenting homosexuality as morally bad is continuously communicated and thus well known, this can already exert a suppressive effect both on the individuals affected and on their potential allies.
} 
2001: 121). This corresponds to the support of influential allies in the movement-countermovement approach seen above.

Authoritative religious bodies can, as shall be demonstrated in the context of this article, consist of denominational leaders, general assemblies of specific denominations, church associations, or the leaderships of Christian universities. Such religious bodies can function as claim makers themselves, or they can assist the members, i.e., constituted actors with privileged or routine access to these bodies, in their fight against their challengers (cf. McAdam et al., 2001: 12). The focus on religious actors does not preclude the possibility that either members or challengers may receive or seek support from authorities external to the religious arena. In fact, it is rather common that actors attempt to appropriate existing organizations or communities to gain benefits and mobilize more effectively (McAdam et al., 2001: 44).

I argue that unlike contention in democratic regimes, many religions or their religious subsets especially fundamentalist factions - do not allow for open deliberation over certain doctrinal and moral aspects of religion, thus impeding the emergence and actions of what one may call a civil society within religion (cf. Tilly \& Tarrow, 2015: 56-58; Tarrow, 2011: 179). Therefore, it can be expected that challengers will resort to transgressive forms of contention. Transgressive contention involves challengers employing innovative collective action, often out of necessity, since contained contention, i.e., using established forms of claim making within existing institutions, may not be available to them (McAdam et al., 2001: 7-8).

Repression may threaten challengers, while transgressive counteraction can in turn represent threats to members. The contentious politics framework calls attention to the fact that such threats - as well as opportunities - only become relevant as soon as they are perceived, and in some cases constructed. As McAdam et al. (2001: 43) argue, “[r]ather than look upon 'opportunities and threats' as objective structural factors, we see them as subject to attribution". The necessity of attribution accentuates the deliberate, strategic construction of opportunities and threats as opposed to the traditional, rather static opportunity structures agenda of social movement studies (McAdam et al., 2001: 14-15). Meyer and Staggenborg also refer to such cognitive and dispositional mechanisms, claiming that the parties to a conflict react dynamically to the actions of the respective opponent and, if the conflict is prolonged, continuously create constraints and opportunities for each other. Consequently, "[t]he opposing movement is a critical component in the structure of political opportunity the other side faces" (Meyer \& Staggenborg, 1996: 1633). While opportunities consist of "the [perceived] probability that social protest actions will lead to success in achieving a desired outcome" (Goldstone \& Tilly, 2001: 182, cited in Tarrow, 2011: 160), threats are commonly perceived ex negativo as "the risks and costs of action or inaction" (Tarrow, 2011: 160). This study emphasizes the productive, opportunitylike potential of threats. In comparison to opportunities and mere grievances, ${ }^{11}$ threats involve a greater sense of urgency and intensity (Almeida, 2019: 44). Tilly (1978: 134-135) argues that "a given amount of threat tends to generate more collective action than the 'same' amount of opportunity." The attribution or creation of threats, I argue, thus represents an attractive tactical choice for the actors involved in contention.

${ }^{11}$ Grievances being defined as "troublesome matters or conditions, and the feelings associated with them - such as dissatisfaction, fear, indignation, resentment, and moral shock" (Snow and Soule, 2010: 23). 


\section{The complex interactions of pro and anti-LGBT actors in Korean Protestantism and beyond}

Regarding the specific constellation of religious actors under investigation in this study, the assumption of a clear-cut picture seems tempting: the actors enforcing anti-LGBT stances within Korean Protestantism can be regarded as the original movement to which LGBT-affirmative counteractors react. However, when taking into consideration non-religious actors as well, the picture becomes more complicated. The Korean anti-LGBT movement can be regarded as a countermovement to begin with, which then engendered opposition from newly forming actors. As Zald and Useem (1987: 249) note, sometimes "a countermovement may in turn generate a countercountermovement that is different from the original movement." Figure 1 illustrates the complex web of contentious interaction in which both pro and anti-LGBT activism within Korean Protestantism are embedded.

Figure 1. Actor constellation and actor overlaps (Venn diagrams) of Protestant and non-religious pro and anti-LGBT actors interrelating with each other and with the state. Source: author's figure.

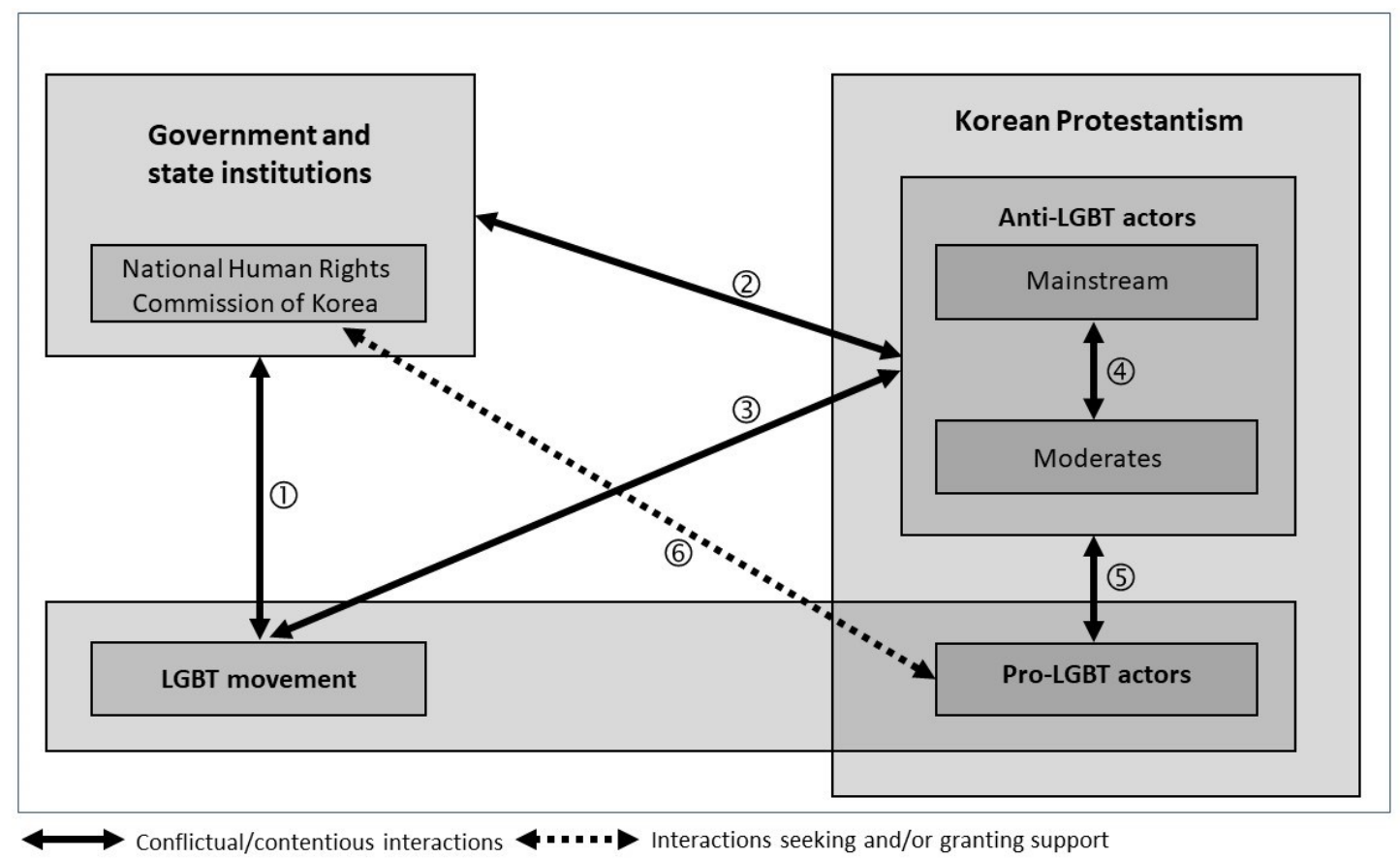

The counter-countermovement, consisting of pro-LGBT activities within Protestantism, emerged only at a later stage in the process of contentious interaction around LGBT issues in Korea (depicted as solid double arrows in Figure 1). While the respective forms of interaction shall be the cornerstone of this analysis, a linear or procedural perspective can illuminate the specific relations among actors and may help identify potential circular interactions. For the sake of clarity, some actor overlaps such as those between governmental actors and the Protestant anti-LGBT camp have been excluded. ${ }^{12}$

12 There have been, for example, ministers and ex-ministers, as well as members of parliament from several political parties, supporting the anti-LGBT movement. 
Figure 1 thus represents a simple, ideal-typical depiction of the actor constellation at hand, with a focus on the actors and interactions relevant to this study.

The Korean LGBT movement represented the initial spark. It emerged in the mid-early 1990s after the democratization of South Korea and started lobbying for LGBT rights (arrow (1) in Figure 1). In response, from the early 2000s onwards, a subset of actors within conservative Korean Protestantism started problematizing LGBT issues. The Christian Council of Korea (CCK), an umbrella organization of conservative Protestant churches, was an early central actor in this respect (Cho, 2011: 303-304), and numerous other Protestant groups and organizations joined this fight. Several groups and coalitions were even newly created, with the main or sole purpose of opposing LGBT rights. ${ }^{13}$ Moreover, several Protestant denominations have included clauses into their church laws condemning and excluding homosexuals in recent years (Paek, 2016). These groups and activists engage in contentious relations both with the LGBT movement and with state actors, which they perceive to excessively promote LGBT rights, purportedly to the detriment of religious freedom of Korean Christians (2), (3).${ }^{14}$

I argue that for large portions of institutional Protestantism in Korea, anti-LGBT stances have become a dominant feature of their faith, which is why I call this group the "mainstream". I use this term also to differentiate these actors from those who hold less vociferous, less exclusionary attitudes towards lesbian, gay, bisexual and trans people. As I will show in the next section, such "moderate" positions - despite being rather unimportant in terms of quantity - face strong opposition from mainstream anti-LGBT forces (4). Finally, there is conflictual interaction between pro-LGBT and anti-LGBT forces within Protestantism (5). These last two types of interrelation will constitute the main focus of the five case studies below. However, actors external to Korean Protestantism also get entangled, at times in a circular manner. As already mentioned, certain state institutions come under fire for their defense of LGBT rights. When Christian pro-LGBT actors then approach these state institutions to seek support against their anti-LGBT opponents (6), the anti-LGBT camp resumes its attacks against the state institution in an even more vigorous manner.

\section{Case studies of contention over LGBT issues within Korean Protestantism}

The cases identified as involving protracted contention over LGBT issues cover a broad range of actors and interactions. Both individual and collective actors become targets of anti-LGBT activism, including the attacks against Pastor Lim Borah and two instances of punishments for pro-LGBT students at Christian universities. Two cases comprise more institutionalized actors, the progressive Christian online newspaper Newsnjoy and the progressive church association NCCK, which are criticized for their LGBT-affirmative stances. Finally, the case of Bundang Woori Church proves relevant as it demonstrates how even slightly dissenting voices can be perceived as a threat. As we

\footnotetext{
${ }^{13}$ Some of the newly established groups have a specialized focus, like the "Korean Association of Family and Health" (han'guk kajok pogón hyŏphoe) dealing with the danger of HIV/AIDS allegedly emanating from LGBT individuals and the "Just Military Human Rights Institute" (parŭn kunin'gwŏn yŏn'guso) fighting against lenient attitudes towards gay men serving in the army. Others like the "Coalition for Moral Sexuality" (parǔn sŏngmunhwa rŭl wihan kungmin yŏnhap) have a broader anti-LGBT focus. Yet others concentrate on the production of online content like the blog "God Man Woman Union” (GMW yŏnhap).

${ }^{14}$ Interestingly, one could argue that the LGBT groups' perception is the exact opposite. From their perspective, state actors are often unwilling, or fail to enact human rights protection for sexual minorities (which, of course, may be due to the powerful anti-LGBT activism of certain Protestant groups). To be clear, I do not argue that the anti-LGBT movement emerged because of or in opposition to the LGBT movement and state actors only. It might also be, e.g., a reaction to more general changes in society (cf. Mottl, 1980).
} 
shall see, these conflicts reflect broader religious and socio-political cleavages in Korean Protestantism and society at large.

\section{(De)certification and scale shift: the heresy trials against Pastor Lim Borah}

Openly LGBT-inclusive congregations are scarce in Korea, but they do exist (Yi et al., 2017). There is even an association of (pro-)LGBT Christians called "Rainbow Jesus", with members from many Protestant denominations and from Catholic Church. Sumdol Hyanglin Church (somdol byangnin kyohoe) is perhaps the most famous of the LGBT-affirmative congregations, with its founding pastor Lim Borah (Im Po-ra) being one of the first in Korean Protestantism to speak out against hatred and discrimination against LGBT people (Schumacher 2016). Sumdol Hyanglin Church belongs to the theologically progressive Kijang denomination (Presbyterian Church in the Republic of Korea, PROK) and is the only Presbyterian congregation in Korea explicitly welcoming sexual minorities (Yi et al., 2017: 1462; Rode, 2018).

Pastor Lim became active in supporting LGBT rights when Protestant anti-LGBT forces began fighting against the inclusion of homosexuality into anti-discrimination bills from 2007 onwards. ${ }^{15}$ She organized discussion events bringing together different Christian views on homosexuality, arguing herself that homosexuals are not objects to be healed or pitied, but that they are part of God's good creation (Yi, T., 2008). Along with other LGBT-affirmative pastors from Rainbow Jesus, Pastor Lim has been a regular attendant of the annual Seoul Queer Culture Festival (SQCF), running a booth and participating in the pride parade (Kang, 2014). The involvement of Christian groups in the SQCF is a recurrent subject of scandal with conservative Christian media (Yi, T., 2018; Ch'oe, 2016). Pastor Lim consistently reaffirmed her strong pro-LGBT attitude and demanded changes in Korean Christianity: "Homosexuality is not a matter of pro or contra, it is about whether we embrace the dignity of a life or not" (as cited in Pak \& Chin, 2014). Pastor Lim also points to the opportunities a welcoming attitude towards LGBT believers could have for her own denomination.

The Presbyterian Church in the Republic of Korea (PROK) is afraid to take the lead role in advocating for human rights of sexual minorities because they worry about additional loss of members, even though they usually like to see themselves as pioneers. I think taking on this matter and openly advocating for the rights of sexual minorities would enrich the profile of PROK. It might even bring new members. Many LGBT Christians are hurt and deeply disappointed by the church and they are longing for a congregation that welcomes them as they are. (as cited in Schumacher, 2016)

Conservative Protestant denominations did not only refuse to follow Pastor Lim's recommendations, but accused her of heresy, that is, beliefs or opinions against the established doctrinal principles of a religion (cf. Tutino, 2012). At the General Assembly of Presbyterian Churches in September 2017, the heresy task forces (idan taech'aek wiwonhoe) of eight major Protestant denominations ${ }^{16}$ demanded that Pastor Lim be declared guilty of heresy. These task forces claimed that her advocacy for homosexuals and her participation in translating the Queer Bible Commentary were unacceptable

\footnotetext{
${ }^{15}$ Anti-discrimination bills were proposed to the Nation Assembly in 2007, 2010, and 2013, but all failed due to strong opposition, mainly emanating from Protestant anti-LGBT groups. The passing of an anti-discrimination law including the categories of sexual orientation and gender identity remains a contentious topic in South Korean socio-political debates to this day.

${ }^{16}$ These denominations included the Presbyterian Church of Korea (PCK, T'onghap), the General Assembly of Presbyterian Church in Korea (GAPCK, Hapdong), the Presbyterian Church of Korea (Daesin), the Kosin Presbyterian Church in Korea (Kosin), the Korean Presbyterian Church (Hapsin), the Korean Methodist Church, the Korea Evangelical Holiness Church, and the Korea Baptist Convention.
} 
and that her interpretation of the Bible constituted an "irrevocable error" as well as a threat to Korean Protestantism (Paek, 2017d). In this investigative process, Pastor Lim Borah was not given any opportunity to defend herself directly (Kang, 2019). Here, the repressive power of churches and their leadership structures becomes evident. The demand to declare Pastor Lim a heretic is a clear example of decertification: powerful actors external to her own denomination tried to delegitimize her.

At the same time, the controversy around this pro-LGBT reverend provided an opportunity to extend the conflict by expanding the number of actors involved. The group "Anti-Homosexuality Christian Solidarity" (AHCS, pandongsŏngae kidok simin yŏndae), for example, joined the chorus of opposition against Pastor Lim by criticizing her mother denomination PROK for allowing such a heretical behavior (AHCS, 2017). This process constitutes a case of scale shift, "a change in the number and level of coordinated contentious actions leading to broader contention involving a wider range of actors and bridging their claims and identities" (McAdam et al., 2001: 311). While the coordinated quality of the contention at hand may be questionable, the extension of the conflict is not. In fact, not only did professionalized anti-LGBT groups join the fight; progressive Christian organizations intervened as well, showing their solidarity with Pastor Lim and by so doing, at least to a certain extent, (re)certifying her. Already when Lim Borah was still under investigation for heresy, the Women's Committee (yŏsŏng wiwŏnhoe) of NCCK issued a supportive statement (Kim, 2017), as did the United Church of Canada, demonstrating international support (Yi, U., 2017b). The "PROK Life Mission Solidarity" (saengmyŏng sŏn'gyo yŏndae) also issued a statement criticizing both the hypocritical behavior of the denominations prosecuting Pastor Lim in light of their own scandals and wrongdoings, and the negative attitude of PROK's general assembly president towards sexual minorities. At a meeting with other denominations' presidents, he had supported a statement against homosexuality and same-sex marriage, thus further isolating PROK's Pastor Lim (Yi, Ŭ., 2017a). These instances of supportive statements for Pastor Lim on the one hand, and dismissive ones on the other, hint at broader underlying conflicts within Korean Protestantism. Moreover, the latter statement by PROK's Life Mission Solidarity evidences that contention over LGBT issues exists even within this progressive denomination. A year later, when the Presbyterian denominations T'onghap and Daesin Paeksŏk actually declared Pastor Lim heretical, PROK displayed a firmer stance, demanding the withdrawal of these decisions and urging the two denominations to apologize to Pastor Lim (Kim, 2018a).

\section{Repressive measures and their implications: punishing LGBT activism at Christian universities}

Contention over LGBT issues can be encountered at Christian universities in Korea as well. In February 2016, theology and missionary students at the Methodist Theological University (kamsin daehakkyo) protested against the Korean Methodist Church's decision to include an official ban on homosexuality into its church constitution. The protesters were all wearing masks hiding their faces, fearing potential consequences following their activism against discrimination (Paek, 2016). However, most LGBT-related activism at Christian universities consists of publicly declaring one's aversion to homosexuality, which has been done by whole universities (e.g. Handong University, Yu, 2017), by groups of Christian professors (Paek, 2017b; Paek, 2017e) and by students (Paek, 2017a).

I will focus on two cases of extended contention over LGBT issues at Christian universities, more specifically conflicts that involved a broader range of actors in protracted interactions. In late 2017, the feminist students club "Wildflower" (tǔlkkot) of Handong University, a private Christian university located in the city of Pohang in south-western Korea, planned to hold a lecture event on prostitution. The university administration forbade this event, but the club proceeded with the event 
regardless, inviting feminist scholars who also talked about polyamory and homosexuality. As a result, Handong University considered taking disciplinary measures against three members of Wildflower, two participants, as well as against a professor who indirectly supported the lecture (Yu, 2018). One student was eventually expelled. ${ }^{17}$

The student club Wildflower challenged the repressive measures taken by their university and filed a complaint with the National Human Rights Commission of Korea (NHRCK). In this action, the students sought help from an institution outside their Christian university and indeed received support (interaction (6) in Figure 1 above). The NHRCK recommended that Handong University withdraw the disciplinary measure as it constituted an act of discrimination of sexual minorities and thus a violation of human rights. Yet, Handong University did not accept this decision (NHRCK, 2019). ${ }^{18}$ In February 2020, a court ruled that while the disciplinary measure taken by Handong University was severe, it was rightful since the lecture event violated the founding philosophy of the school (Chang, 2020).

The NHRCK was established in 2001 as an independent state agency to protect and advocate human rights in Korea. As soon as the NHRCK started an investigation of the Wildflower incident, contention became more heated and shifted towards the NHRCK as the main target. Christian parents' groups staged several protests in front of the NHRCK building in Seoul, gathering up to 300 participants (Paek, 2019b). Press statements reprimanding the NHRCK for infringing on the religious and academic freedom of Christian universities were also issued by various Christian organizations. ${ }^{19}$ The Korean Association of Church Communication (ban'guk kyohoe ŏllonhoe, KACC), mouthpiece of the conservative parts of Korean Protestantism such as the CCK, even demanded that the NHRCK be dismantled: "[..] the National Human Rights Commission of Korea [...] should be dissolved to properly stop the destruction of human dignity and values, and to stop it putting undue pressure on schools that practice correct teaching" (KACC, 2019a). It is remarkable that although the lecture event organized by the student club Wildflower was predominantly about issues other than homosexuality, most of the statements overemphasize this aspect, accusing the NHRCK of taking a biased stance, overly favoring LGBT rights as against the freedom of religion (Paek, 2019a; Yu, 2019; Paek, 2018).

Similar repressive measures against pro-LGBT activism were taken by Changshin University, another private Christian university in south-western Korea, located in the city of Changwon. Commemorating the international day against homophobia on May 17, 2018, eight students of the student club "Am-ha'aretz" dressed in rainbow-colored clothes and entered the altar area holding a rainbow flag after a church service at Changshin University. The group shared pictures of this

\footnotetext{
${ }_{17}$ A related case concerns the lecturer Kim Tae-ok who was dismissed from Handong University for not meeting the requirements for reappointment. Kukmin Daily reported that reasons for his dismissal could be found in his lack of opposition against homosexuality and his support for the student club Wildflower $(\mathrm{Ku}, 2018)$. Kim Tae-ok was subsequently found guilty of heresy in a decision "to protect the Korean church" taken by the general assembly of the Presbyterian Paeksŏk denomination in September 2019. "Pastor Kim Tae-ok interprets the Bible arbitrarily, teaches greatly wrong ideas in core doctrines, and advocates Islam and homosexuality" (cited in Yi, Ü., 2019c).

18 The NHRCK issued a similar recommendation to protect the human rights of sexual minorities in a case that occurred at Soongsil University, a private Christian University in Seoul. The university had prohibited the screening of a movie as the university deemed the film to show a beautifying image of homosexuality (NHRCK, 2019).

${ }_{19}$ Press statements were issued by, among others, the "Handong University Parents' Prayer Association" (bandong taehakkyo hakpumo kidohoe), the "Christian Voters Union" (ban'guk kidokkyo yugwŏnja yŏnhap), and the "National Union of Professors against the Legalization of Homosexuality and Same-Sex Marriage” (tongsŏngae tongsŏnghon hapbŏphwa pandae chŏn'guk kyosu yŏnhap) (Paek, 2018; Paek, 2019a; Yu, 2019).
} 
rainbow performance on social media. The university leadership did not approve of this action and immediately started an investigation of the students involved, asserting that they violated the regulations of the school and of the T'onghap denomination Changshin University belongs to. In a press statement, the students expressed their disappointment with the university's actions, claiming that their rights of freedom of expression and freedom of conscience were infringed (Yi, Y., 2018). ${ }^{20}$ Nonetheless, in July 2018 four students were suspended from attending Changshin University. With the support from "Hope and Law" (hǔimang ǔl mandǔnǔn pŏp), a lawyers' association advocating human rights, the penalized students successfully appealed against their university's verdict. As opposed to the Wildflower case, a court decided in July 2019 that their suspensions were invalid, albeit only due to procedural flaws (Yi, U., 2019b). In a press statement, the KACC condemned this decision and accused the court of showing disrespect for Christianity. The KACC (2019b) also demanded Changshin University to take disciplinary measures against the students yet again - this time legally - in order to protect the church and society at large from an unwanted influx of homosexuality. The KACC statement reveals the ideological and political implications of Protestant anti-LGBT activism by further elaborating on the alleged dangers of homosexuality:

Homosexuality cannot simply be regarded as encompassing sexual minorities or the weak, but it is a ruse conceived by Satan, which aims to destroy the church through 'Cultural Marxism'. Homosexuality is not just a matter of sex, it is sex politics, it is sex ideology, it is sex revolution. What they seek to do is destroying Christian values, families, society, and the church as a whole. (KACC 2019b)

While disparaging homosexuality is a common feature of KACC press releases, it is striking that a relatively minor rainbow performance provokes such a strong response. Indeed, any activism in favor of homosexuality - no matter how innocuous - is met with dramatic allegations such as an intent of church destruction, social decay, and communist conspiracy. ${ }^{21}$ In such a discursive environment, engaging in LGBT-affirmative activism entails high risks for the people involved. When Protestant denominations, universities, and specialized anti-LGBT organizations dominate the discourse and institutionalize anti-LGBT stances, established ways of deliberation, e.g. at denominational general assemblies, are no longer available. Pro-LGBT actors have to resort to other means, consistently risking shaming, disciplinary measures, and exclusion. Under such circumstances, even seemingly small acts of dissent represent transgressive and potentially threatening actions.

The repressive measures against students who are (perceived to be) fighting for LGBT rights on campus are already noteworthy phenomena in themselves. Even more remarkable, though, is the fact that a broader range of Protestant anti-LGBT actors only mobilized as soon as these "incidents" created a stir also outside the Christian arena - another example of scale shift. When the NHRCK got involved in the Wildflower case at Handong University, other Protestant anti-LGBT forces started mobilizing, staging protests and issuing press statements. Similar furor emerged when a court

\footnotetext{
${ }^{20}$ In the press statement, "Am-ha'aretz" also claim that they are not affected by the church regulation since it only mentions staff members of universities and not students. The church constitution of the Presbyterian Church of Korea T'onghap states in article 26-12: “Those who support and advocate homosexuals and homosexuality are against the teachings of the Bible, and those who support and advocate homosexuals and homosexuality shall not be members of the Church and professors and faculty members of the Theological University." Moreover, the students argued that the university regulations did not mention homosexuality at all (Yi, Y., 2018).

${ }^{21}$ South Korea's geo-political and historical background is the reason for a general favoring of argumentative strategies building on anticommunism (Kim et al., 2015). Furthermore, in recent years, the Korean anti-LGBT movement and other right-wing political actors worldwide have been increasingly using the narrative of "cultural Marxism", a conspiracy theory claiming that basically anything far-right actors deem evil, such as political correctness, multiculturalism, "big government", LGBT rights, and feminism, derives from the neoMarxist teachings and strategies of the Frankfurt School theorists Adorno, Horkheimer, and Marcuse (Mirrless, 2018).
} 
rendered a verdict in favor of the rainbow performance students. This extended contention brings to light even more fundamental conflicts that have been shaping Korean Protestantism. The liberal political and judicial elites (or those libeled as such) in general and governmental institutions like the NHRCK in particular have been longstanding targets of attacks by conservative Protestants. ${ }^{22}$ This church-state antagonism enables, and contributes to counteraction. If this cleavage emerges in conflicts internal to Protestantism as well, the purported threat becomes greater and counteraction more urgent. Furthermore, if this is the case, anti-LGBT actors can resort to well-established arguments and action repertoires more easily.

\section{Reproducing the progressive/ conservative divide: the cases of Newsnjoy and NCCK}

Institutional Protestant actors like the progressive Christian online newspaper Newsnjoy and the theologically liberal church association NCCK (National Council of Churches in Korea) have been under attack for their support of LGBT issues as well. Anti-LGBT groups take issue, for example, with Newsnjoy's positive reporting on LGBT topics. In December 2018, a pastor of the AntiHomosexual Christian Solidarity started organizing several rallies against Newsnjoy. The protesters decried this "anti-Christian press" as a "destructive force that infiltrated the church" and as a supporter of communism, demanding that churches supporting Newsnjoy financially halt their funding (Kim, 2018b; cf. also Chang, 2019). Subsequently, the "National Association of Professors against the Legalization of Homosexuality and Same-Sex-Marriage"23 issued a statement condemning Newsnjoy's critical articles on Christian anti-LGBT activists in particular. Newsnjoy "is the newspaper most supportive of homosexuality among domestic media, it has a strong hostility toward anti-homosexual activism and is releasing all kinds of malicious articles" (Kang, 2019). Newsnjoy features a section in which it conducts fact checks of "fake news" produced by representatives of the anti-LGBT movement. Viewing this kind of reporting as acts of defamation, several anti-LGBT activists sued Newsnjoy. In January 2020, a court ruled that Newsnjoy had to pay compensations for reporting "beyond the scope of legitimate media activities of monitoring, critique, and checking" and demanded that the articles in question be deleted (Paek, 2020a). ${ }^{24}$ In March 2020, the gay mens' organization "Chingusai" announced that Newsnjoy would receive the 14th rainbow human rights award for being the only media within the Korean Christian community to actively fight against hatred and discrimination against minorities (Paek, 2020b).

As an association including liberal Protestant denominations, the $\mathrm{NCCK}^{25}$ is also a frequent target of conservative Protestant critique. Like Newsnjoy, the NCCK has the potential of reaching many church members - threatening the image agitated for by the anti-LGBT camp of the Korean churches standing united against homosexual "evils". Theologically positive perspectives on homosexuality

\footnotetext{
${ }^{22}$ The NHRCK is mainly criticized for the inclusion of "sexual orientation" in its anti-discrimination mandate (article 2 of the NHRCK act). Courts have been targets of conservative Protestant protest on many occasions, too. For example, Protestant groups tried to exert influence on trials of the Supreme Court, fighting successfully against the lift of the ban on homosexuality in the Korean military, but unsuccessfully against the elimination of a strict prohibition of abortions.

${ }^{23}$ Although the name of this professors' group suggests differently, homosexuality has never been officially criminalized on the state level in Korea. Only the military penal law of South Korea includes a provision (article 92-6) punishing sex between men. Historically, however, this provision has not been implemented until recently.

${ }^{24}$ As of October 14, 2020, the fact checking articles of Newsnjoy were still accessible in full online, suggesting that Newsnjoy appealed the court ruling.

${ }^{25}$ NCCK's member denominations include, for example, the Presbyterian Church in the Republic of Korea (PROK, Kijang), the Anglican Church of Korea, the Lutheran Church in Korea, but also more conservative ones like the Korean Orthodox Church, the Assemblies of God of Korea, and the Presbyterian Church of Korea (PCK, T'onghap) (NCCK 2020).
} 
and related subjects directly call into question the conservatives' worldview and fundamentalist interpretation of the Bible. Therefore, the NCCK was met with fierce and partly violent protests when, for example, it published a translated theological book on homosexuality (Pak, 2015). The NCCK was also criticized when it invited a gay film director who advocates same-sex marriage for a lecture event on anti-discrimination (Sin and Paek, 2016), and when it demanded that the political parties in the newly elected National Assembly quickly pass an anti-discrimination law (KACC, 2020). The latter controversy on NCCK's advocacy for the anti-discrimination law illustrates the broader socio-political and religious cleavages underlying the contention over LGBT issues. The "Christian Liberty Unification Party" (kidok chayu t'ongildang), a minor right-wing Christian political party, for example, in a press statement denounced NCCK as a left-wing religious political force:

They [the NCCK] claim they are active for the weak who are faced with discrimination and want to realize justice, but in fact, they habitually shout the political slogans of the Democratic Party [Korea's ruling party] on fake equity and fake peace like parrots, thereby advocating the anti-discrimination law which would legalize actions to promote homosexuality and to destroy the church and normal social culture. (cited in $\mathrm{Yu}, 2020$ )

Rivalry does not only exist in the area of political inclinations, but also among Korean Protestant associations. The leader of the conservative Christian Council of Korea (CCK), for instance, joined a rally against the NCCK, decrying its support for the anti-discrimination law (Chi 2020). There are also calls for the NCCK, the CCK and other conservative church associations ${ }^{26}$ to reunite in order to strengthen Korean Protestantism, but the NCCK's promotion of homosexuality and its alleged support of North Korea are presented as making such an endeavor impossible. Therefore, the KACC argues, it would be better to no longer recognize NCCK as a church association (KACC, 2016).

Contention over LGBT issues renders visible the rifts that run deeper than simple disagreements over the theological or ethical assessment of homosexuality. Longstanding conflicts between ideologically, theologically, and politically opposing parts of Korean Protestantism come to the fore here. Anti-LGBT forces strategically use well-established arguments to disavow their internal enemies, such as anti-communism and nationalism, when maintaining that by advocating progressive issues, the NCCK, Newsnjoy, and others willfully damage not only the church, but also families and the country as a whole. The fault lines, however, do not run merely between progressive and conservative Protestant forces. They are also observable within conservative Protestantism itself, as the next case exemplifies.

\section{Critique, backlash, and strategic accommodation: the case of Bundang Woori Church}

On June 5, 2019, a junior pastor of Bundang Woori Church (pundang uri kyohoe), a missional church located in the city of Seongnam south of Seoul, committed an act he would come to regret afterwards. In a sermon that was televised online but later deleted, he claimed that the obstinate and uncompromising focus on homosexuality shed a negative light on Korean Protestantism. In his view, people engaging in activism against homosexuality lost track of societal trends and could thus be regarded as "kekondae", a derogatory appellation for people with outdated values which they try to impose on others in a more or less aggressive way. Although the junior pastor also voiced his view that from a Biblical perspective homosexuality was a sin, his sermon was met with immediate and

\footnotetext{
${ }^{26}$ Conflicts exist within organized conservative Korean Protestantism, too. For example, 20 denominations split from the CCK in 2012 due to disagreement over the election of a new leadership, forming the Communion of Churches in Korea (CCIK, ban'guk. kyohoe yŏnhap) (Paek, 2017c).
} 
fierce backlash from within the church. Protestant anti-LGBT activists denounced him and the senior pastor of Bundang Woori Church as advocates of leftist and anti-Christian ideas, resulting in several official apologies and reaffirmations of the two pastors' strong anti-gay stance. The junior pastor promised he would not preach for the duration of one year after this incident, and the senior pastor announced he would establish a Christian research institute on the topic of homosexuality (Yi, Ŭ., 2019a).

This episode illustrates how even moderate attitudes towards LGBT issues are met with fierce resistance from anti-LGBT forces within South Korean Protestantism. Anti-LGBT groups have not only presented the actions of the Bundang Woori Church junior pastor as a threat for the Korean church. Other prominent church actors have also been criticized if they or their entourage are not in alignment with the hegemonic anti-LGBT discourse. For instance, the anti-LGBT group AHCS demanded an apology from the chairman of the South Kyŏngsang Province Christian Council (kyŏngnam kidokekyo ch'ongyŏnhaphoe) as a reaction to his son's promotion of queer theology via social media (AHCS, 2018). Another peculiar example concerns the leadership of Chongshin University, a private Christian university in Seoul belonging to the conservative Hapdong denomination, which came under fire from anti-LGBT groups for dismissing a homophobic professor. Students had taken issue with the professor teaching in a bioethics lecture that homosexual acts were against the creation order and harmful to health (Im, 2020).

The fierce verbal attacks against Bundang Woori Church are surprising, since its senior pastor had actively preached the sinfulness of homosexuality in the past (The Bible-smith Project, 2016). It seems as though the junior pastor's sermon did not come under attack so much for his relatively moderate stance on homosexuality. Rather, the reason for being faced with an immense backlash is the fact that the junior pastor - very much like Newsnjoy - openly attacked the anti-LGBT factions of Korean Protestantism. The act of pointing out critical aspects of anti-LGBT activism from within conservative Protestantism poses a particular threat to the intended image of a united church. Therefore, the Protestant anti-LGBT movement immediately and forcefully responded to the junior pastor's announcements. Their response proved effective: with the announcement to create a Christian research institute in order to deal with the problem of homosexuality, the senior pastor publicly demonstrated his willingness to atone for the "mistakes" committed. In a sense, Bundang Woori Church appears keen to become an overachiever as a means to convincingly prove its firm anti-LGBT attitude. Such a behavior can be called strategic accommodation, a kind of "dramatic ingratiation" to (re)gain the favor of certain actors by "fostering the impression that values, aims, and/or conduct are in conformity with, or at least not incongruent with, certain values, traditions, and normative standards within the ambient society" (Snow, 1979: 30, cited in Snow \& Beyerlein, 2019: 579).

The threat posed by the junior pastor's sermon is productively used by the anti-LGBT movement. The anti-LGBT actors achieved their goal of forcing Bundang Woori Church to "realign" with the anti-LGBT mainstream. They set another warning example for all those who may hold similar affirmative or just moderate opinions and are pondering whether to act upon them. So Kang-sŏk, a senior pastor of New Eden Church (sae eden kyohoe), a mega-church located in the city of Yongin south of Seoul, is both an active member of the Protestant anti-LGBT movement and a frequent contributor to the Kukmin Daily. In a column, he analyzes the "exhausting controversy" around Bundang Woori Church and put forward an interesting comparison: 
The historian Toynbee said that if a civilization succeeded in responding to an external challenge, such as a harsh natural environment or external invasion, that civilization could continue and develop. If it fails, the civilization disappears behind the stage of history. Interestingly, civilizations that have not been challenged have gone a path of collapse. [...] In this sense, the attack of anti-Christian forces on the Korean church is a good challenge for us. If the Korean church does not accept this challenge but makes compromises, it will surely go extinct. Recently, there was an exhausting controversy over the issue of homosexuality in the Korean church. However, by resisting the opinion that homosexuality is only a mayfly and that this trend has already ended, Korean churches have succeeded in becoming one again. (So, 2019)

This passage allows for an insight into the logics underlying the opposition against pro-LGBT tendencies within Protestantism. While LGBT-affirmative actions and attitudes are perceived and/or presented as acute threats to the church, families, and to the society as a whole, they also constitute opportunities - opportunities to reiterate anti-LGBT arguments, to reinvigorate and thus mobilize church members, and to recreate an image of a church standing united against inimical groups. The internal enemy thus becomes a productive force for anti-LGBT activism.

Whether such opportunities "pay off” for the anti-LGBT forces in the long run remains questionable, though. As I have shown, pro-LGBT actors are increasingly visible and assertive within Korean Protestantism. The continuous and relentless activities of the Protestant anti-LGBT forces certainly played its part in propelling counteractors into existence. To some extent, the threat emanating from anti-LGBT activism creates opportunities for pro-LGBT actors, too, and increases the urgency for resistance. Admittedly, counteraction has been minor and scattered so far, certainly when compared to the excessive anti-LGBT reactions that ensued. There are also many who are intimidated by the ferocious anti-LGBT forces and the effects they yield, such as the reproduction and reinforcement of homophobic attitudes in Christian families. But others refuse to endure the ubiquitous repression, discrimination, and hatred in their churches any longer. They stage rainbow performances, they openly participate in queer events and seek support from external institutions if necessary, making the existence of Christian LGBTs and their allies a visible reality in South Korean Protestantism.

\section{Conclusion}

This article has explored the contention between anti and pro-LGBT actors within Korean Protestantism, focusing on the relational, cognitive, and constructivist aspects at work in such interactions. I have suggested that the perception and attribution of threat play important roles in opposing LGBT-affirmative tendencies. The greater the threat, the more active anti-LGBT activism gets. Anti-LGBT actors themselves strategically increase the threat by engaging in extreme allegations such as church destruction, communist collaboration, and imperilment of the nation. Anti-LGBT counteraction is particularly strong when external opponents such as the NHRCK enter the conflict in defense of LGBT rights. In such cases, the anti-LGBT movement often resorts to established narratives and action repertoires. The enlarged threat thus opens up greater opportunities to attack the opposing forces. In other words, if the "internal enemy", i.e., the pro-LGBT activists within Korean Protestantism, is joined by the "external enemy" (Han, 2017), ferocious counteraction is considered even more urgent.

Socio-political and church-internal cleavages are deeply rooted in the history of Korean Protestantism. These denominational and ideological rifts break open in the contention over LGBT issues as well. Anti-LGBT actors try to win over whole church communities, thereby creating a 
religious "regime" that often acts repressively against LGBT individuals and LGBT-affirmative attitudes. Alongside other action repertoires such as protests and issuing press statements, concrete repressive measures represent a common action form in this context, consisting of punishing proLGBT students and declaring pastors heretical. These attempts at delegitimization do not go unchallenged, though. Pro-LGBT actors also receive support from within and outside the church, encouraging them to remain steadfast against endeavors to exclude and denigrate them. Others, however, when faced with fierce backlash, quickly refrain from their moderate attitudes and engage in even more diligent anti-LGBT activities as a result, as the case of Bundang Woori Church reveals.

This study demonstrated that several mechanisms like scale shift, certification and decertification, and the attribution of threat can be observed in the contentious interactions of pro and anti-LGBT actors within Korean Protestantism. Applying the contentious politics and movementcountermovement frameworks to the study of religious conflict thus proved fruitful, in particular as it allowed for a new take on the actors involved such as state-like, repressive authoritative religious bodies. Future research could continue on this avenue and apply this approach to other cases of contention involving religious actors, both in Korea and beyond. This way, one could test if similar mechanisms and action repertoires are observable in further instances of LGBT-related struggles. One should also consider comparing the mechanisms uncovered in this study with those at work in the broader socio-political contention over LGBT issues in Korea. The interactions between antiLGBT forces and secular state actors in particular, which this investigation revealed to be of great significance for anti-LGBT mobilization, should become an object of detailed examination, including a thorough analysis of its ideological background (anti-communism and nationalism), which this study could only cursorily cover.

\section{References}

Almeida, P. D. (2019). “The Role of Threat in Collective Action”. In: D. A. Snow, S. A. Soule, H. Kriesi, \& H. J. McCammon (eds.) The Wiley Blackwell Companion to Social Movements, Hoboken: Blackwell.

Anti-Homosexual Christian Solidarity (2017, September 4). Pandongyŏn sŏngmyŏng_kijang kyodan Im Po-ra moksa rŭl myŏnjiksik'yŏra [Press statement of the Anti-Homosexuality Christian Solidarity_Kijang denomination, dismiss pastor Lim Borah]. http://www.antihomo.net/ info01/view?p=6\&article_id=201

Anti-Homosexual Christian Solidarity (2018, July 17). Kyŏngnam kich’ong hoejang xxx moksa nǔn adǔl xxx chŏndosa ǔi idan k'wiŏ sinhak ongho e taehae ch'aegim chigo sagwahara! [Pastor xxx, chairman of the South Kyŏngsang Province Christian Council, you have to take responsibility and apologize for your son XXX's promotion of the heretical queer theology!]. http://www.antihomo.net/ statement/view?p=3\&article_id=506

Baek, J. (2018). Han'guk posu kaesinkyo sŏngsosuja hyŏmo tamnon ǔi hyŏngsŏng kwa chŏngae yangsang: 'sŏnggwahak' chisik ǔl t'onghan hyŏmo chaegusŏng [Anti-Sexual Minorities Discourses Constructed by Korean Conservative Protestant Churches: Politics of Disgust in the Name of Scientific Knowledge]. Master's thesis.

Baker, D. L. (2016). "The impact of Christianity on modern Korea: an overview". Acta Koreana, 19 (1): 45-67. https://doi.org/10.18399/acta.2016.19.1.002

Béraud, C., \& Portier, P. (2015). "Mariage pour tous': The Same-Sex Marriage Controversy in France”. In: K. Dobbelaere \& A. Pérez-Agoto (eds.) The Intimate. Polity and the Catholic Church: Laws about Life, Death and the Family in the So-Called Catholic Countries, Leuven: Leuven University Press.

Bong, Y. D. (2009). "The Gay Rights Movement in Democratizing Korea". Korean Studies, 32: 86-103. https://doi.org/10.1353/ks.0.0013

Buswell, R. E. Jr., \& Lee, T. S. (eds.) (2006). Christianity in Korea. Honolulu: University of Hawai'i Press.

Chang, C. (2020, February 21). Pŏbwŏn "handongdae, tajasŏngae kang'yŏn chuch'oehan haksaeng chinggye nǔn chŏngdang" [Court: "The punishment for a student who hosted lecture on polyamory is proper]. Kukmin Daily. http://news.kmib.co.kr/article/view.asp?arcid=0924124105 
Chang, M. (2019, January 8). 'Nyusǔaenjoi' pinan e koppi p'ullin pandongsŏngae chinyŏng [Anti-homosexual camp gets unbridled, faced with critique from Newsnjoy]. Newsnjoy. http://www.newsnjoy.or.kr/ news/articleView. html?idxno $=221967$

Chi, Y. (2020, April 22). Posu kaesinkyo tanch'e, 'NCCK' kyut'an kisǔp siwi... kǔ iyu nǔn? [Conservative Protestant groups hold surprise protest condemning NCCK... Why?]. OhmyNews. http://www.ohmynews.com/ NWS_Web/View/at_pg.aspx?CNTN_CD=A0002635349\&CMPT_CD=P0010\&utm_source=naver\&utm_me dium $=$ newsearch\&utm_campaign $=$ naver_news

Cho, M. (2011). "The Other Side of their Zeal: Evangelical Nationalism and Anticommunism in the Korean Christian Fundamentalist Antigay Movement since the 1990s". Theology \& Sexuality, 17 (3): 297-318. https://doi.org/10.1179/tas.17.3.xx56t21243207121

Ch'oe, Y. (2016, August 18). “Ch'ongsindae enǔn tongsŏngaeja tongari ŏpda”... k’wiŏ ch’ukche ch'amgaja ch'ongsindae myŏng ǔi toyong ["There is no homosexual club at Chongshin University"... A participant of the queer festival stole its name]. Kukmin Daily. http://news.kmib.co.kr/article/view.asp?arcid=0010867878

Choi, E. (2014). "Religion, Religiosity, and Socio-Political Attitudes in South Korea". Korea Observer, 45 (2): $321-$ 346.

Clark, D. N. (2008). "Protestant Christianity and the state: religious organizations as an example of civil society in South Korea". In: S. Pares (ed.) The Past and the Present (2 volumes): Selected Papers from the British Association for Korean Studies Baks Papers Series, 1991-2005, n.p.: Global Oriental.

Coley, J. S. (2018). Gay on God's Campus: Mobilizing for LGBT Equality at Christian Colleges and Universities. Chapel Hill: University of North Carolina Press.

Coley, J. S. (2017). "Reconciling Religion and LGBT Rights: Christian Universities, Theological Orientations, and LGBT Inclusion”. Social Currents, 4 (1): 87-106. https://doi.org/10.1177/2329496516651639

Coley, J. S. (2014). "Social Movements and Bridge Building: Religious and Sexual Identity Conflicts". Research in Social Movements, Conflicts, and Change, 37 (1): 125-151. https://doi.org/10.1108/S0163786X20140000037005

Dorf, M. C., \& Tarrow, S. (2014): "Strange Bedfellows: How an Anticipatory Countermovement Brought Same-Sex Marriage into the Public Arena”. Law \& Social Inquiry, 39 (2): 449-473. https://doi.org/10.1111/1si.12069

Dugan, K. B. (2004). “Strategy and 'Spin': Opposing Movement Frames in an Anti-Gay Voter Initiative”. Sociological Focus, 37 (3): 213-233. https://doi.org/10.1080/00380237.2004.10571243

Fejes, F. (2008). Gay Rights and Moral Panic: The Origins of America's Debate on Homosexuality. New York: Palgrave Macmillan.

Fetner, T. (2008). How the Religious Right Shaped Lesbian and Gay Activism. Minneapolis: University of Minnesota Press.

Goldstone, J. A.; \& Tilly, C. (2001). “Threat (and Opportunity): Popular Action and State Response in the Dynamics of Contentious Action”. In: R. R. Amnizade et al. (eds.) Silence and Voice in the Study of Contentious Politics, New York: Cambridge University Press.

Green, J. C. (2000): “Antigay: Varieties of Opposition to Gay Rights”. In: C. A. Rimmerman, K.D. Wald, \& C. Wilcox (eds.) The Politics of Gay Rights, Chicago and London: The University of Chicago Press.

Han, C. (2017). Wae han'guk kaesinkyo nǔn 'tongsŏngae hyŏmo' rŭl p'iryoro hanǔnga? [Why does the South Korean Protestant church need 'hatred against homosexuality'?]. In: Chŏng, H. (ed.): Yangsŏng p'yŏngdǔng e pandaehanda [Opposing gender equality], n.p.: Gyoyangin.

Hark, S., \& Villa, P. I. (eds.) (2015). Anti-Genderismus: Sexualität und Geschlecht als Schauplätze aktueller politischer Auseinandersetzungen. Bielefeld: Transcript Verlag.

Hedström, P., \& Ylikoski, P. (2010). "Causal Mechanisms in the Social Sciences". Annual Review of Sociology, 36: 49-67. https://doi.org/10.1146/annurev.soc.012809.102632

Herman, D. (1997). The Antigay Agenda: Orthodox Vision and the Christian Right. Chicago: The University of Chicago Press.

Hwang, J. (2008). "A Study of the Fundamentalist Tendency in Korean Protestantism: With Special reference to the Korean Presbyterian Church". Acta Koreana, 11 (3): 113-142.

Im, P. (2020, January 28). Tongbanyŏn, Yi Sang-wŏn kyosu e ch'uga chinggyesim ŭi hanǔn ch'ongsindae chaedan isahoe kyut'an [Tongpanyŏn condemns Chongshin University Foundation board of directors for considering additional disciplinary measure]. Kukim Daily. http://news.kmib.co.kr/article/view.asp?arcid=0014174447

Kang, I. (2004). "Protestant Church and Wolnamin: An Explanation of Protestant Conservatism in South Korea". Korea Journal, 44 (4): 157-190. 


\section{Opportunities and Threats in Pro and Anti-LGBT Activism within South Korean Protestantism}

Kang, J. (2013, October 28). The Kukmin Daily: The world's only Christian general-interest paper. Kukmin Daily. http:/ $/$ www.kukmindaily.co.kr/article/view.asp?page $=\& g C o d e=7111 \& \operatorname{arcid}=0007695884 \&$ code $=71111101$

Kang, J. (2014, June 6). Yesunim ŭn tongsŏngae rŭl ottǒke taehasilkka [How would Jesus treat homosexuality?]. Kukmin Daily. http://news.kmib.co.kr/article/view.asp?arcid=0008394549

Kang, T. (2019, January 25). Pandongsŏngae kwangp'ung gwa 20 nyŏn hu han'guk kyohoe [Anti-homosexuality craze and Korean Church 20 years later]. Newsnjoy. http://www.newsnjoy.or.kr/news/articleView. html?idxno= 222194

Kim, D., Pohlmann, C., \& Szèll, G. (eds.) (2015). Pangong ǔi sidae: han'guk kwa tog'il, naengjŏn ǔi chŏngch'i [The age of anti-communism: Korea and Germany, cold war politics]. Seoul: Tolbaegae.

Kim, N. (2016). The Gendered Politics of the Korean Protestant Right. Palgrave Macmillan.

Kim, J. (2017, August 10). NCCK “Im Po-ra moksa idan sibi e ch'amdam [NCCK declares "The dispute around pastor Lim Borah is a tragedy"]. Christian Today. https://www.christiantoday.co.kr/news/303047

Kim, J. (2018a, September 13). Kijang "Im Po-ra moksa e taehan idanmori kwangp'ung mŏmch'wŏra [PROK demands that "the heresy with hunt against pastor Lim Borah has to stop"]. Christian Today. https://www.christiantoday. co.kr/news/316011

Kim, J. (2018b, December 18). “Kyohoe p'agoe seryŏk nyusǔaenjoi, chŏngch'e rŭl palk’yŏra!” Destructive force for the church, Newsnjoy, reveal your identity!']. Christian Today. https://www.christiantoday.co.kr/news/318534

Kim, J. (2019). Han'guk ǔi in'gwŏn tamnon kwa chŏngch'aek - p'ogwaljŏk ch'abyŏlgǔmjibŏp ippŏb ǔi chedojŏk kyŏngno wa tamnon ǔi yŏkhal [Human Rights Discourse and Policy in Korea - The Institutional Path of AntiDiscrimination Act and Role of the Discourse on Human Rights]. Yonsei University, PhD thesis.

Kniss, F., \& Burns, G. (2004). Religious Movements. In: D. A. Snow, S. A. Soule, \& H. Kriesi (eds.): The Blackwell Companion to Social Movements, Malden: Blackwell.

Korean Association of Church Communication (2016, May 18). Kyŏkpyŏnhanǔn sahoe, han'guk kyohoe kyodan yŏnhap kigwandǔl hana doeŏya [In a rapidly changing society, Korean church associations have to become one]. http:/ /168.126.51.180/board/?r=home\&m=bbs\&bid=commentarypds\&iframe=Y\&p=10\&uid=977

Korean Association of Church Communication (2019a, January 10). Kukka in'gwŏnwi ka 'makchang dǔrama' taebon ǔl ssŭnŭnga? [Is the National Human Rights Commission of Korea writing a 'soap opera' screenplay?]. http://168.126.51.180/board/? $\mathrm{r}=$ home\&m=bbs\&bid=commentarypds\&p=2\&uid=1224

Korean Association of Church Communication (2019b, July 23). Pŏbwŏn ǔi tongsŏngae mujigae sagŏn, haksaeng chinggye muhyo kyŏljŏng [Decision of court that punishment of students involved in the homosexuality rainbow incident is invalid]. http://chprorg.dlinkddns.com/board/?r=home\&m=bbs\&bid=commentarypds\& iframe= Y\&uid $=1279$

Korean Association of Church Communication (2020, April 23). NCCK, chŏngsin ch'ari sipsio! [NCCK, please come to your senses!]. http://chprorg.dlinkddns.com/board/?r=home\&m=bbs\&bid=commentary pds\&iframe= Y\&uid $=1344$

Ku, C. (2018, January 3). Handongdae, tongsŏngae pandaehaji annǔndanǔn iyu ro kyojikkwŏn haeim nollan [Handong University, controversy over dismissal of faculty members for not opposing homosexuality]. Kukmin Daily. http://news.kmib.co.kr/article/view.asp?arcid=0012024051

Kuckartz, U. (2014). Qualitative Inhaltsanalyse. Methoden, Praxis, Computerunterstützung. Weinheim: Beltz Juventa.

Kwon Kim, H., \& Cho, J. (2011). “The Korean gay and lesbian movement 1993-2008”. In: G. Shin, \& P. Y. Chang (eds.) South Korean Social Movements. From democracy to civil society, London: Routledge.

Mayring, P. (2015). „Qualitative Inhaltsanalyse“. In: U. Flick, E. Kardoff, \& I. Steinke (eds.) Qualitative Forschung. Ein Handbuch, Reinbek bei Hamburg: Rowohlt Taschenbuch Verlag.

McAdam, D., \& Tarrow, S. (2011). "Introduction: Dynamics of Contention Ten Years On". Mobilization: An International Quarterly, 16 (1): 1-10. https://doi.org/10.17813/maiq.16.1.61m83k7n14813365

McAdam, D., Tarrow, S., \& Tilly, C. (2001). Dynamics of Contention. Cambridge: Cambridge University Press.

Meyer, D. S., \& Staggenborg, S. (1996). "Movements, Countermovements, and the Structure of Political Opportunity”. American Journal of Sociology, 101 (6): 1628-1660. https://www.jstor.org/stable/2782114

Mirrless, T. (2018). “The Alt-Right's Discourse of 'Cultural Marxism': A Political Instrument of Intersectional Hate”. Atlantis Journal, 39 (1): 49-69.

Moon, D. (2014). "Beyond the Dichotomy: Six Religious Views of Homosexuality". Journal of Homosexuality, 61 (9): 1215-1241. https://doi.org/10.1080/00918369.2014.926762 
Mottl, T. L. (1980). “The Analysis of Countermovements”. Social Problems, 27 (5): 620-635. https://doi.org/ $10.2307 / 800200$

National Council of Churches in Korea (2020). Hoewŏn, yugwan kigwan [Members and related institutions]. http://www.kncc.or.kr/eventView/member

National Human Rights Commission of Korea (2019, May 7). Sŏngsosuja in'gwŏn ch'imhae mit ch'abyŏl kwŏngo haedang taehaktǔl pulsuyong [Recommendation on human rights violations and discrimination against sexual minorities unacceptable to universities concerned]. https://www.humanrights.go.kr/site/program/board/ basicboard $/$ view? \&boardtypeid $=24 \&$ menuid $=001004002001 \&$ pagesize $=10 \&$ boardid $=7604082$

Paek, S. (2016, February 21). Sinhaktae kkaji pŏnjin 'tongsŏngae ongho' ... daehak mada ongho moim hwaldong uryŏ ['Support of homosexuality' even at theological universities... Concern that each university has such support groups and activities]. Kukmin Daily. http://news.kmib.co.kr/article/view.asp?arcid=0923435710

Paek, S. (2017a, August 8). 43 kae daehaksaengdǔl "tongsŏngae tongsŏnghon hŏyong hŏnbŏp kaejŏng pandae" [Students of 43 universities "oppose the permission of homosexuality and same-sex marriage through constitutional amendment”]. Kukmin Daily. 2020 http:// news.kmib.co.kr/article/view.asp?arcid=0923795354

Paek, S. (2017b, August 11). Taehaksaengdǔl iǒ kyosu 2204 myŏng "tongsŏngae happŏhwa kaehŏnan pandae" [2204 professors follow university students in declaring "opposition against the legalization of homosexuality and against the constitutional amendment"]. Kukmin Daily. http://news.kmib.co.kr/article/view. asp?arcid $=0923797135$

Paek, S. (2017c, August 27). Hankiyŏn, hankich'ong, NCCK... yŏnhap kigwan ǔl asinayo [Do you now the church associations Hankiyŏn, CCK, and NCCK?]. Kukmin Daily. http://news.kmib.co.kr/article/view. asp?arcid $=00117$

07548

Paek, S. (2017d, September 4). 8 kae kyodan “Im Po-ra, idanjŏk kyŏnghyang”... Im moksa “ponmaljŏndo pulk'wae” [Eight denominations declare "Lim Borah has heretical tendency"... Pastor Lim says "mistaking the means for the end is unpleasant]. Kukmin Daily. http://news.kmib.co.kr/article/view.asp?arcid= 0923809885 \&code=23111113 $\& \mathrm{cp}=\mathrm{nv}$

Paek, S. (2017e, September 26). Ch'imsindae kyosudǔl “tongsŏng kyŏlhon happŏphwa pandae” sŏngmyŏngsŏ [Professors of Korea Baptist University issue statement "opposing the legalization of same-sex marriage]. Kukmin Daily. http://news.kmib.co.kr/article/view.asp?arcid=0011785560

Paek, S. (2018, April 4). Handongdae hakpumodǔl "In'gwŏnwi, kidokkyo sŏllip chŏngsin ch'imhae malla" [Parents of Handong University: "National Human Rights Commission, don't violate the foundational spirit of Christianity”]. Kukmin Daily. http:// news.kmib.co.kr/article/view.asp?arcid=0012251276

Paek, S. (2019a, January 8). Tongbangyoyŏn “tajasŏngae maech'un ǔl in'gwŏn ŭro p'ojanghan in'gwŏnwi kyut'an" [National Union of Professors against the Legalization of Homosexuality and Same-Sex Marriage: "We condemn the NHRCK for presenting polyamory and prostitution as human rights"]. Kukmin Daily. http://news.kmib.co.kr/article/view.asp?arcid=0012973831

Paek, S. (2019b, January 23). "Kajja in'gwŏn ǔro kidokkyo malsal" handongdae hakpumodǔl siwi [Christianity will be annihilated by fake human rights", protest of Handong University parents]. Kukmin Daily. http://news.kmib.co.kr/article/view.asp?arcid=0924058177

Paek, S. (2020a, January 20). "Nyusǔaenjoi, tongsŏngae silch'ae allin kangsa, maech'e e ch'ong 3000 man wŏn paesanghara" ["Newsnjoy has to pay 30 million Won as compensation to a lecturer and to media outlets that inform about the truth on homosexuality]. Kukmin Daily. http://news.kmib.co.kr/article/ view.asp?arcid=0924118872

Paek (2020, March 27). Kungnae ch'oedae ǔi gei tanch'e ka nyusǔaenjoi e sang ǔl chundago? [The biggest gay group in Korea gives an award to Newsnjoy?]. Kukmin Daily. http://news.kmib.co.kr/article/ view.asp?arcid $=0014415229$

Pak, C. (2015, December 17). NCCK “tongsŏngae kongnon ǔi chang e naenok'o taehwahae pwaya” [NCCK: "Let's have a public conversation on homosexuality]. Kukmin Daily. http://news.kmib.co.kr/article/ view.asp?arcid=092 3362204

Pak, C., Chin S. (2014, October 19). Kat'ollik ch'oejong pogosŏ 'tongsŏngae' ŏngǔp sakche... kyogye panǔng ['Homosexuality' deleted from Catholic final declaration... Reactions of churches]. Kukmin Daily. http://news.kmib.co.kr/article/view.asp?arcid=0008776455

Pak, P. (2018). 'T'aldongsŏngae undong' ǔi kanjǔng sŏsa wa kǔ chŏllyak: yut'yubǔ ǔi t'aldongsŏngaeja kusul yŏngsang (2013-2017) punsŏk [The ex-gay movement's testimony narration and strategy: analysis of YouTube videos with oral statements of ex-gays (2013-2017)]. Master's thesis. 
Park-Kim, S., Lee-Kim, S., \& Kwon-Lee, E. (2006). "The Lesbian Rights Movement and Feminism in South Korea”. Journal of Lesbian Studies, 10 (3/4): 161-190. https://doi.org/10.1300/J155v10n03_11

Rich, T. S. (2016). "Religion and Public Perceptions of Gays and Lesbians in South Korea". Journal of Homosexuality, 64 (5): 606-621. https://doi.org/10.1080/00918369.2016.1194122

Rode, E. (2018, April 25). Amid anti-gay sentiment, LGBT-affirming churches provide fellowship and advocacy. The Groundtruth Project. https://thegroundtruthproject.org/amid-anti-gay-sentiment-small-community-lgbtaffirming-churches-provide-fellowship-advocacy/

Schumacher, K. (2016, November 22). From hurt to welcome: an interview with Rev. Bora Lim, South Korea. Affirm United. https://affirmunited.ause.ca/from-hurt-to-welcome-an-interview-with-rev-bora-lim-south-korea/

Shiwoo (2018). K'wiŏ ap'ok'allipsŭ: sarang kwa hyŏmo ŭi chŏngch'ihak [Queer Apocalypse: The Politics of Love and Hatred]. Seoul: Hyunsilbook.

Sin, S., \& Paek, S. (2016, April 29). NCCK in'gwŏn sent’ŏ, “ch'abyŏl omnǔn sesang ǔl kkumkkunǔn iyagi madang e taehan p'ongnyŏkchŏk panghae nǔn pulbŏb haengwi” [NCCK Human Rights Center: "Disturbing the talk dreaming of a world without discrimination in violent ways is an illegal activity"]. Kukmin Daily. http://news.kmib.co.kr/article/view.asp?arcid $=0010576140$

Snow, D. A. (1979). "A Dramaturgical Analysis of Movement Accommodation: Building Idiosyncrasy Credit as a Movement Mobilization Strategy”. Symbolic Interaction 2: 23-44. https://doi.org/10.1525/si.1979.2.2.23

Snow, D. A., \& Beyerlein, K. (2019). "Bringing the Study of Religion and Social Movements Together: Toward an Analytically Productive Intersection". In: D. A. Snow, S. A. Soule, H. Kriesi; \& H. J. McCammon (eds.) The Wiley Blackwell Companion to Social Movements, Hoboken: Blackwell.

Snow, D. A., \& Soule, S. A. (2010). A Primer on Social Movements. New York: W.W. Norton.

So, K. (2019, August 27). Sion ǔi sori: tojŏn ǔn kǔkpogiji t'ahyŏb i anida [The voice of Zion: the challenge is to overcome, not to compromise]. Kukmin Daily. http://news.kmib.co.kr/article/view.asp?arcid=0924094861

Stone, A. L. (2016). "The Impact of the Anti-Gay Politics on the LGBTQ Movement". Sociology Compass, 10 (6), 459-467. https://doi.org/10.1111/soc4.12373

Tarrow, S. (2011). Power in Movement. Social Movements and Contentious Politics (revised and updated 3rd ed.). New York: Cambridge University Press.

The Bible-smith Project (2016, May 12). Pundang uri kyohoe chuil yebae tongsŏngae nŭn choe da(1) by Yi Ch'an-su moksanim 20160501 [Bundang Woori Church Sunday service: homosexuality is sin (1), by pastor Yi Ch'an-su 20160501] [video file]. https://www.youtube.com/watch?v=jqZ2bvGZuNQ

Tilly, C. (2001). "Mechanisms in Social Processes". Annual Review of Political Science, 4: 21-41. https://doi.org/10.1146/annurev.polisci.4.1.21

Tilly, C. (1978). From Mobilization to Revolution. Reading, MA: Addison-Wesley.

Tilly, C., \& Tarrow, S. (2015). Contentious Politics (2nd ed.). Oxford: Oxford University Press.

Tutino, S. (2012). "Heresy". In: M. Juergensmeyer, \& W. D. Roof (eds.) Encyclopedia of Global Religion, Los Angeles: Sage.

Yi, J., Jung, G., \& Phillips, J. (2017). "Evangelical Christian Discourse in South Korea on the LGBT: the Politics of Cross-Border Learning”. Society, 54 (1): 29-33. https://doi.org/10.1007/s12115-016-0096-3

Yi, J., Jung, G., Segura, S. S., Phillips, J., \& Park, J. Z. (2017). “Gay Seouls: Expanding Religious Spaces for NonHeterosexuals in South Korea". Journal of Homosexuality, 65 (11): 1457-1483. https://doi.org/10.1080/00918369.2017.1377492

Yi, T. (2008, January 30). 'Sŏnggyŏng ǔn hanande...' Tongsŏngae kyŏnhae kǔk kwa kǔk ['The Bible is one...' Extremely different opinions on homosexuality]. Christian Today. https://www.christiantoday. co.kr/news/190216

Yi, T. (2018, July 16). Chae 17 hoe k’wiŏ chukche sok 'kidokkyo'? ['Christianity' at the 17th Queer Festival?]. Christian Today. https://www.christiantoday.co.kr/news/314371

Yi, Ǔ. (2017a, August 5). "Im Po-ra moksa koripsik'in ch'onghoejang sagwahara“ ["President of the general assembly who isolated pastor Lim Borah, apologize to her!’]. Newsnjoy. http://www.newsnjoy.or.kr/news/articleView. html?idxno $=212447$

Yi, Ŭ. (2017b, August 17). K'aenada yŏnhap kyohoe "Im Po-ra moksa wa yŏndaehanda" [The United Church of Canada "shows solidarity with pastor Lim Borah"]. Newsnjoy. http://www.newsnjoy.or.kr/news/articleView. html?idxno=212609

Yi, Ǔ. (2019a, June 11). ‘Tongsŏngae ishyu ro sikkǔrŏun bundang uri kyohoe: pandongsŏngae chinyŏng, sŏlgyo ilbu hwaktae haesŏkhae pumoksa maengbinan... pumoksa, nollan ilja tu ch'arye sagwa [Bundang Woori Church noisy with 'homosexual issue': the anti-homosexual camp overinterprets part of a sermon and harshly condemns junior 
pastor... the junior pastor apologizes two times for this controversy]. Newsnjoy. http://www.newsnjoy.or.kr/ news/articleView.html?idxno $=223954$

Yi, Ŭ. (2019b, July 18). Pŏbwŏn 'mujigae p'ŏp'omŏnsǔ' changsindae haksaengdǔl chinggye 'muhyo' [Court: punishment against students of Changshin University who did a 'rainbow performance' was 'invalid']. Newsnjoy. http://www.newsnjoy.or.kr/news/articleView.html?idxno=224488

Yi, Ǔ. (2019c, September 20). Yejang paeksŏk, handongdae chŏn kyomok Kim Dae-ok moksa 'idan' chŏngjoe [Pastor Kim Dae-ok, a former school chaplain at Handong University, is guilty of 'heresy']. Newsnjoy. http://www.newsnjoy.or.kr/news/articleView.html?idxno=225190

Yi, Y. (2018, May 21). Changsindae, sŏngsosuja wihae 'mujigae' kitpal tǔn haksaengdǔl chosa [Changshin University investigates students who held up a rainbow flag for sexual minorities]. Newsnjoy. http://www.newsnjoy. or.kr/news/articleView.html?idxno $=217778$

Yu, S. (2018, January 8). P'aeminijǔm kangyŏn chunbihaettago haksaengdǔl chingye nasŏn handongdae [After declaring they wanted to organize a feminist lecture Handong University takes action and punishes students]. Kyŏnghyang Sinmun. http://news.khan.co.kr/kh_news/khan_art_view.html?art_id=201801080600045

Yu, Y. (2017, May 26). Handongdae, kungnae daehal ch'oech'o-ro tongsŏngae tongsŏng kyŏlhon pandae ch'ŏnmyŏng [Handong University becomes the first university in Korea to declare its opposition against homosexuality and same-sex marriage]. Kukmin Daily. http:// news.kmib.co.kr/article/ view.asp?arcid=0011495868

Yu, Y. (2019, February 2). Han'guk kidokkyo yugwŏnja yŏnhap sŏngmyŏng “kukka in'gwŏnwi nǔn tongsŏngae ongho chǔkkak chungdanhara" [Korean Christian Voters Union: "NHRCK has to stop advocating homosexuality immediately]. Kukmin Daily. http://news.kmib.co.kr/article/view.asp?arcid=0013038077

Yu, Y. (2020, April 22). Kidok chayu t'ong'ildang "tongsŏngae ongho ch'abyŏl kǔmjibŏp chejŏng NCCK kyut'an" [Christian Liberty Unification Party: "We condemn NCCK for supporting the passing of the anti-discrimination law which would promote homosexuality]. Kukmin Daily. http://news.kmib.co.kr/article/view. asp?arcid $=001450$ $3940 \&$ code $=61221111 \& \mathrm{cp}=\mathrm{nv}$

Zald, M. N., \& Useem, B. (1987). "Movement and Countermovement Interaction: Mobilization, Tactics, and State Involvement”. In: M. N. Zald, \& J. D. McCarthy (eds.) Social Movements in an Organizational Society, New Brunswick: Transaction. 